\section{Nations for Mental Health}

The World Health Organization has established a special program to promote mental health in underserved populations. Designated "Nations for Mental Health," this new program seeks to improve mental health and psychosocial well-being worldwide, with emphasis on populations whose access to mental health services has been limited.

Nations for Mental Health is designed as a special program within the United Nations system, initiated and coordinated by WHO. As noted by a former UN Secretary-General, the objective of the $\mathrm{UN}$ system as a whole "is to promote the mental health and well-being of all the inhabitants of the planet." The program will concentrate on the following main areas:

- National mental health plans.

- Improvement of services and treatment.

- Human rights and legislation.

- Empowerment of consumers and families.

- Promotion of mental health and prevention of mental disorders, with special emphasis on women, children, and adolescents.

- Special mental health programs to benefit refugees and indigenous populations.

One of the program's objectives is to draw greater public and governmental attention to the effects of mental health problems and substance abuse on the social well-being and physical health of the world's underserved populations. A first step toward meeting this objective is to increase awareness of the importance of mental health through a series of high-profile events. Key political authorities will be encouraged to participate, and efforts will be directed at securing the political commitment of decision makers. The special program aims to create an international process of sensitization and to build political will and commitment for viewing mental health issues as a major public health problem and tackling stigmatization and discrimination.

A second objective is to identify and promote collaborative strategies for improving mental health that can be implemented through countrylevel technical cooperation projects by organizations of the United Nations system, in cooperation with other international governmental and nongovernmental organizations. Special emphasis will be given to projects that focus on children in diffi- 
cult circumstances, abused women, people traumatized by violence, people addicted to alcohol or drugs, people suffering from chronic mental illness, and those living in extreme poverty.

The program will establish a number of demonstration projects in each of the six WHO regions. These projects are meant to illustrate the potential of collaborative efforts at the country level and serve as prototypes for larger-scale projects. Several demonstration projects have already been initiated-in Argentina, Sri Lanka, Vietnam, and Yemen, and among indigenous populations in Brazil, Canada, and some Pacific islands-and others are under consideration.

The general public, health decision-makers, and most of the professional medical community are insufficiently aware of the extent and nature of mental disorders and of the social and economic cost that they represent for those who suffer from them, for their families, and for countries. Although mental and behavioral problems do not appear as leading causes of death, they rank among the top 10 causes of long-term disability, often affecting people during their most productive years and leaving traces throughout life.

As the disabling effects of mental illnesses impose a heavy social and economic burden, implementation of this global program demands the joint mobilization of social, economic, and political forces as well as substantive changes in governmental policies related to education, health, and economic development in each country. Thus, this ambitious program needs an intense and sustained effort by the nations of the world, through joint cooperation among governments, nongovernmental organizations, and specialized agencies within the UN system. Its implementation depends upon voluntary contributions from governments, foundations, individuals, and other sources.

For further information, please contact: Director, Division of Mental Health and Prevention of Substance Abuse, World Health Organization, 20 Avenue Appia, 1211 Geneva 27, Switzerland (fax +41 22 7914160; telephone +41 22 7913617).

\section{SINOPSIS}

\section{Naciones unidas para la salud mental}

La Organización Mundial de la Salud ha establecido un programa especial denominado "Naciones unidas para la salud mental" con el fin de fomentar la salud mental en poblaciones subatendidas, con particular énfasis en las mujeres, los niños, los adolescentes, los refugiados y los pueblos indígenas. Uno de los objetivos del programa es crear una mayor conciencia entre el público y los gobiernos acerca del costo social y económico de los trastornos mentales y del abuso de sustancias. Un segundo objetivo es identificar y promover estrategias de colaboración para mejorar la salud mental que se puedan poner en práctica por medio de proyectos de cooperación técnica de nivel nacional dirigidos por las organizaciones del sistema de las Naciones Unidas, en colaboración con otras organizaciones internacionales gubernamentales y no gubernamentales. Ya están en marcha varios proyectos de demostración y otros se están planificando. 